\title{
The New Categorizations of Style in Contemporary Islamic Calligraphy Paintings in Malaysia
}

\author{
Nor Azlin Hamidon and Siti Mastura Md. Ishak
}

\begin{abstract}
Islamic contemporary paintings stand as one of the identities of the nation. The pluralisme of its styles has been depending mainly towards the classification of Muslim artworks introduced by Ismail Raji Al-Faruqi in 1986. Due to the expansion of art media, its technique, individual quality and aesthetic experience, this paper intends to search for the new styles emerged from the amalgamation of the three art traditions: Islamic, Western and Malay art, from the study made on Islamic calligraphy paintings selected from year 1947 until 2005. Among 707 paintings collected, 110 have been selected as samples to represent the diversity of the material, year, artist and painting technique. These paintings have been scrutinized using qualitative method (grounded theory) and the final finding introduces 5 main styles which could accommodate in precise the paintings into its own suitable categories based on the latest art mainstreams.
\end{abstract}

Index Terms-Art style, classification of Islamic art, contemporary Islamic calligraphy, Malaysian art.

\section{INTRODUCTION}

Islamic calligraphy in contemporary art of Malaysia is one of the art phenomena in the history of the revitalization of traditional art in contemporary world. It does not stand alone in this issue as many other traditional crafts such as textile, ceramic, woodcarving and metal craft are also invigorated in the new form and function. However, the main issue in contemporary art phenomena is the problem to classify the artworks into appropriate styles, especially on the Islamic calligraphy paintings which have received the influence of three main art streams and civilizations, namely Western, Arabic and Malay. The research done for this article includes 110 samples out of 707 artworks collected from all over Malaysia. The samples are the source of classifications and reclassifications, until the established styles materialize.

\section{Literature REVIEW}

The Islamization of arts and material culture depends largely on the theory of "Qur'anic art" proposed by Ismā'̄il Rājī al-Fārūqī and his wife, Lois Lamyā' al-Fārūqī [1]. Al-Fārūqī's theory was based on al-Qur'ān as the source of Islamic art received a tremendous support by many muslim scholars throughout the world. According to him, the styles of contemporary Islamic calligraphy could be categorized into five categories: a) Traditional Calligraphy; b) Figural

Manuscript received January 14, 2014; revised March 5, 2014

Nor Azlin Hamidon is with the University of Malaya (e-mail: norazlin@um.edu.my).
Calligraphy; c) Expressionist Calligraphy; d) Symbolic Calligraphy; and e) Pseudo-Calligraphy or Pure Abstraction. This had been used during the 1980's and a decade afterwards but the development and expansion of new art form critically questions the limitation of these five art styles.

Nada M. Shabout [2] in her doctoral thesis, Modern Arab Art and The Metamorphosis of the Arabic Letter, concerns on the Western influences in shaping Middle Eastern cultures and how those that were adopted from the West were systematically Arabised, through intellectual approaches, and how, despite persistent Western influences, a contemporary Arab art, an art with unique Arab elements operating within Arab aesthetic values which not only expresses Arab cultures but also takes part as a potential factor in constructing new realities and identities. Examining only art works of two major artists, Shakir Hassan Al-Said and Dia al-Azzawi, the conclusion recapitulates the salient points of the study, discussing the suitable classification of style for modern Arab art.

The latest study at doctoral level on contemporary Islamic painting in Malaysia was done by Ahmadrashidi bin Hasan[3]. The objective of the study is to establish the historical development of the contemporary Islamic art in Malaysia in the 1980 's and 1990 's, as well as to identify the determinant factors of styles of the decades. The study applies Panofsky's theory of Iconology [4] over 83 samples of paintings. The findings are to lead the identification of styles and meaning, especially towards the establishment of Islamic art as a term to define certain contemporary works.

From the study on literature, there has been an expansion of styles from the study of Middle Eastern art works by Shabout, whereas Ahmadrashidi in trying to define the term Islamic art in contemporary art works of Malaysia had neglected to formulate the categorization of styles as Shabout did. Therefore, there is indeed a need towards the study of the new dimensions of art styles in Malaysia, especially related to Islamic calligraphy.

\section{OBJECTIVES}

This research intends to aim at three objectives as follow:

- to collect data of contemporary Islamic calligraphy paintings of Malaysia;

- to find an appropriate approach in studying Islamic calligraphy and categorizing the art works; and

- to formulate the new categorizations of style based on the analysis of form, context and content of the art works. 


\section{Methodology AND THEORETICAL FrAMEWORK}

The methodology used for this study is qualitative, especially by using grounded theory. Art works of Malaysian artists containing Islamic calligraphy of any style and use will be included in this research. The main concern is to choose an appropriate theory, as it analyses form and content of Islamic art which has a close relationship with the sacred words of God. The study on the theories in art history reveals the possibility of common appreciation on art in general, but when it comes to the specific approach and understanding of art from certain perspective under certain worldview such as Islamic spirituality and transcendence, the theories certainly contain incompatibility in terms of concepts and approaches. Hence, it is vital to build an appropriate approach in the discipline of art history in recognizing cultural objects of a culture, moreover, in adjescent to the philosophy of life of the society under study.

For this study, the theory of Iconology is chosen, proposed by Erwin Panofsky who introduced three levels of interpretations:

- Pre-iconographical description (and pseudo-formal analysis), which relies on practical experience (familiarity with objects and events)

- Iconographical analysis in the narrower sense of the word (familiarity with specific themes and concepts), which relies on knowledge of literary sources

- Iconographical interpretation in a sense (Iconographical synthesis). The equipment for this level is synthetic intuition (familiarity with the essential tendencies of the human mind), conditioned by personal psychology and Weltanschauung.

The main matter to be reconsidered in this theory is the question of philosophical differences in the equipment for interpretation. Thus, a comparative theory is included in developing a new theory, i.e. Islamic epistemological theory of al-Ghazzālī [5] which had been chosen to represent the Islamization of Islamic Art, in theory and methodology. The theory of "The History of Muslim Art Tradition" is developed for this study, especially for the researchers who are interested in studying Islamic art.

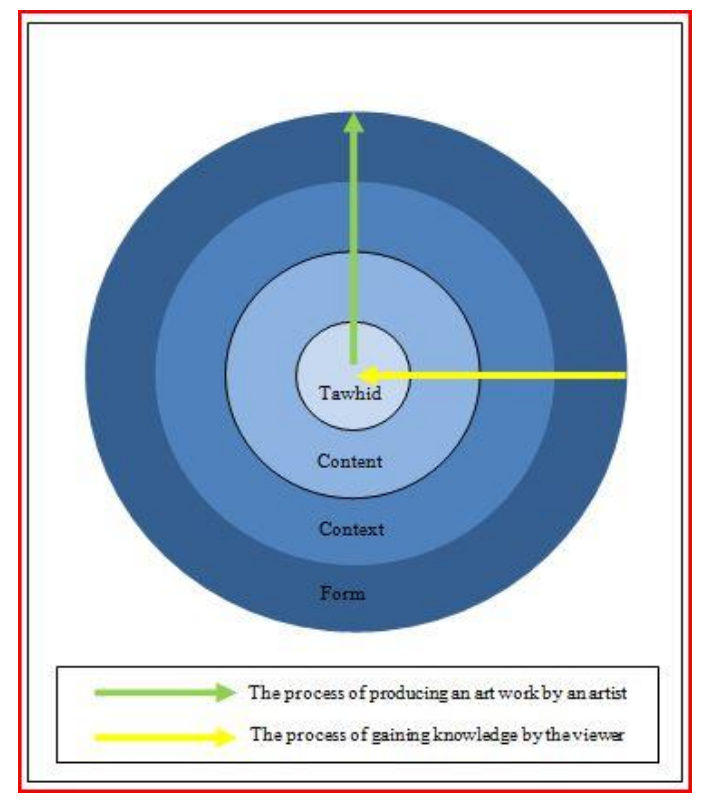

Fig. 1. The Theory of the history of Muslim art tradition.
The theory of "The History of Muslim Art Tradition" is an adaptation between the theory of Iconology and the theory of epistemology by Al-Ghazzali [6]. Other than the three equipments of interpretation introduced by Panofsky to interprete art works, Al-Ghazzali has defined another tool or equipment of interpretation which has the element of spirituality and transcendence. The source of knowledge comes from the God by means of The Holy Words or the Hadith of the Prophet Muhammad s.a.w. Whereas the concept of intuition bears the different meaning; it is totally not a human process of thinking, but knowledge granted by God towards the chosen people. This new proposed theory is nothing but a suggestion to approach the Islamic art material in an additional level which includes the meaning through the Islamic revelation. The direction of this research is conducted initially from the study of form; and then move to the second level towards the perusal on the context. The third level of interpretation depends on the ability of the mind to synthesize the art works which will define the theme and content. The direction to the center is a search for the deepest meaning; for the source of direction and action, where the ambiance of the spiritual experience may be represented by the forms, the composition and the symbolism. Hence, the overall process will formulate the History of Muslim art tradition. This theoretical framework, which has been designed for deducing the history of contemporary art, hold to the objective of Islamic art concepts, especially in elevating the concept of Tawhìd as the ultimate goal of Muslim art.

\section{SAMPLES AND ANALYSIS}

The study has successfully collected 707 art works since the production year of 1947 until 2005. They are collected from personal collections, galleries and museums. Among these works, only 110 works are carefully chosen as samples for the study. The selection of 110 art works out of 707 were based on its uniqueness found in these art works: media, years of production, exhibited art works and maximum number of art works selected from an artist. It should be stressed that there are two art works found from the early decades (1940's until 1950's), one for each decade, and both are chosen for this study. In 1960's, only five out of twelve art works selected, representing $41.6 \%$ as sample. The art works of the early decades are very small in number simply because not much documentation had been done, especially before the establishment of National Art Gallery in 1958 or of any other galleries and museums in Malaysia. It is also due to the priority in selecting art works and its quality. Since 1970 's onwards, the selected art works total to $16 \%$ to $25.53 \%$ of the production of the decades. However, the number of samples is increasing from 1950's onwards. The exact percentage of selected art works are as shown in the Table I.

The sample of art work is not only based on the year of production, but also the unique characteristics and the number of artists it represents. Therefore, the number itself symbolizes only one part of the whole collection. Other qualities, such as the event, medium, technique, the structure of the form and the type of calligraphy are also considered before making it as samples for this research. 
TABLE I: COMPARISON OF NUMBERS BETWEEN THE SAMPLES AND ACTUAL COLLECTED PiCTURES OF ISLAMIC CALLIGRAPHY ART WORKS.

\begin{tabular}{|c|c|c|c|}
\hline Decade & $\begin{array}{c}\text { Total of } \\
\text { Pictures Taken }\end{array}$ & Samples & $\begin{array}{c}\text { Percentage of } \\
\text { Sample }\end{array}$ \\
\hline 1940's & 1 & 1 & $100 \%$ \\
\hline 1950's & 1 & 1 & $100 \%$ \\
\hline 1960's & 12 & 5 & $41.6 \%$ \\
\hline 1970's & 47 & 12 & $25.53 \%$ \\
\hline 1980's & 110 & 19 & $17.27 \%$ \\
\hline 1990's & 200 & 32 & $16 \%$ \\
\hline 2000's & 231 & 41 & $17.7 \%$ \\
\hline
\end{tabular}

Analysis has been done on form and content. The study of form concerns on the size, orientation, media, technique, form and shape, as well as the underlying structures and composition of background of the art works. In order to study the content, art works are put into the context; as well as study on the text. Based on the art scenario of Malaysia; the selection of verses quoted in the art works; and the meaning supplied by the compositional design and visual language; the new categorization of styles emerged. These are in lieu with the development of technology, media and technique applied in the art works.

\section{THE FINDINGS: STYLES OF CONTEMPORARY ISLAMIC CALLIGRAPHY PAINTINGS}

The basis of categorization is the form and content. These categorizations could not be created without studying both form and content. They are also arranged based on the hierarchy, starting from the most sacred towards the mundane categories. After scrutinizing all the samples, these categorizations emerged: Traditional Calligraphy, Rudimentary Calligraphy, Abstract Calligraphy, Marginal Calligraphy and Gestural/Pseudo-Calligraphy.

\section{A. Traditional Calligraphy}

It is a classification that refers to the calligraphy executed in one of the established rules of traditional Islamic calligraphy. The style of writing could easily be recognized according to the classification of traditional types of calligraphy such as Küfí, Thuluth, Muhaqqaq, Raihānī, Naskh, Dīwānī, Dīwānī Jalī, Fārisī, Bīḥārī, Andalūsī, Maghribī, Șiñī and many others.

\section{1) Neo-classical calligraphy}

The works generally are the revivals of the past Muslim ancestors's works, the repetition with or without the changes in scripts or motifs, or the execution of writing according to strict rules of writing calligraphy. The style of writing is usually plain letters; composed in formal straight horizontal line or lines; coloured in solid style. This complies with works such as Al-Maghfur Lahu (1947), by Mohd Salleh Hassan Farid and Allahu Waliyyu Al-Taufiq (1988) by Nik Farhan Mustapha.

The calligraphy must retain its linguistic significance, means that it has to be recognized letters (when the letters combined, it provides a meaning), words and sentences. The main attributes of this category is not only beautiful in the execution of letters and words, but meaningful as well. This includes the calligraphy done in using computer softwares, facsimilies and reproduction of classical works.

\section{2) Modern classical calligraphy}

It refers to the strict traditional rules of writing, but combined with modern composition. The calligraphy is done in superimposed, three-dimensional spatial forms, not solid (gradient) in colouring technique. It could be the reproduction of traditional works, or a new style of writing, but specially composed in various styles and techniques. The formal and geometrical shape calligraphy is included in this category, for example: September Series II (1992) by Khatijah Sanusi; Ya Karim Akrimni (1997) by Mohammed Yusof Abu Bakar; Ayat Al-Qursi (Kufi) (1998) by Omar Rahmat; Tidak Melayu Hilang Di Dunia (1999) by Adam Musa; Ya Karim (2000) by Zainurrahman Afandi; Khat Nasakh (Sürah Al-zalzalah) (2001) by Shafie Hassan; Sürah al-Mursalāt 77: $41-42$ (2001) by Syed Ubaidillah Syed Mohamad; Surah Al-Rahman 55: 24 (2001) by Zainurrahman Afandi; Surah Al-Mukminin 23: 29 (2002) by Mohammed Yusof Abu Bakar and many others.

The same implication of meaning as in the Neo-Classical Calligraphy category applies in this category as well. The calligraphy must retain its linguistic significance, means that it has to be comprehensible combinative letters, words and sentences. The main attributes of this category is not only beautiful in the execution of letters and words, but meaningful as well.

\section{3) Free form calligraphy}

This refers to recognized types of traditional calligraphy, but certain features of the letters had been changed to fit the shape the artists had stipulated and created earlier. Letters had been elongated, shortened, squeezed and manipulated to fill in a shape of figural representation, either non-living things or living things.

The non-living thing forms from the samples are represented in the forms of ship, torch, stars, moons, seal and dome. This is represented in Surah Al-Dukhan: 53 (1976), by Wan Salleh Fathi Wan Isa; Seni Rupa Bangsa (1981) by Jamilpin; Ilmu Punca Kemajuan (1981) by Mohamed Hamzah Mohd Yatim; Surah Al-Ikhlas (1988) by Yahya Khatib Yusop; and Mohor Hitam Putih, (1991) by Riaz Ahmad Jamil Ahmad.

For the living thing shapes, the samples involve the shapes of aquatic, in-land (and flying) animals, such as in Basmalah in the Shape of Fish (1980) by Syed Muhammad Naguib Al-Attas and Basmalah in the Shape of Bird (1983) by Nik Zainal Abidin Nik Salleh.

The calligraphy must retain its linguistic significance. The main attributes of this category is mostly the beautiful feature in the execution of letters to certain forms but still meaningful. Some of the words are hardly legible.

\section{B. Rudimentary Calligraphy / Modern Calligraphy}

This category refers to any letters, words or sentences executed in personal style of writing, undeveloped style, non-compliance of any traditional rules of writing. The meaning is presented by the combined letters, words or sentences, but the presentation of the style of writing has its own additional meaning, usually expressive and symbolistic as in modern style. 
For example, in the work of Zafar Aliff Zafaruddin, Munajat Series: Shari'at, Tarikat, Hakikat, Makrifat, (2001) - the individual letters of Alif, Lām, Lām and $\bar{a}$ stand for the word "Allāh", but on its own, each letter represents four basic elements of the world: dirt, water, fire and air.

Other samples are from the works of Abdul Ghaffar Ibrahim (1977) entitled Cacing and in sample Ta Alif Nun $\mathrm{Ha}$ - Tanah (1985). Both are the representation of the rudimentary calligraphy that repeats the same words over the surface of painting: Cacing in one work and Tanah in the other. Both works Cacing and Tanah were not only repeating the words, but presented in the form of the meaning. Therefore, the words are themselves iconic.

\section{Abstract Calligraphy}

This is where the visual aesthetic aspect of the letter is manipulated as a structural element in the composition as an autonomous graphic form. It comprises two forms of scripts:

\section{1) Legible script}

Comprises of the recognizable individual letters; sometimes perfectly and beautifully executed as the scripts followed the traditional rules of writing but devoid of any linguistic significance.

For example, Ahmad Khalid Yusof in his work Alif Ba Ta (1971); Abdul Ghani Othman with his two works Belajar Jawi Rumusan I (1995) and 38 Fonem (1996) show the individual letters as the basis of recognizing the fonems at initial stage of reading and writing. The letters stands for nothing except as the sign of phonetic significance.

However, an exceptional sample occurs in the sample by Abu Bakar Idris, namely Wafa and Water (2001). The 9 individual letters were intentionally arranged in a square, divided in 9 similarly distributed boxes known as magic square. The letters themselves do not stand as phonetic icon, but relate to certain symbols of mystical qualities.

\section{2) Calligraffiti}

It is called calligraffiti because it is close to graffiti scribbling. Parts of the letters or words are comprehensible but most are not. It is executed only for total decomposition and destruction of meaning embodied in the letter as part of the language. It does not carry any message within its letters, so the calligraphic form becomes a strictly constructional pattern similar to the arabesque where the scripts are transformed to abstract signs.

This could be refered in sample by Ahmad Khalid Yusof, titled Jawi and Nature 13 (1984); and sample by Irwan Idris, titled I (2001), The other work is by Siti Zainon Ismail in sample Gelora Gelombang Jugra (1997).

\section{Marginal Calligraphy}

It is a category when the calligraphy becomes subordinate to or mixed with other components in the composition. Other visual components are dominating the work; and the existence of calligraphy in a painting either illegible or not; produced to replicate the original view of a scene; in which the existence of its own does not deliver any messages in the strokes of line or expressive on its own. Its existence, somehow, contributes to the message of the whole painting, such as the indication of time and space in the cultural settings. (For example, Dzulkifli Buyong in Paper Boat
(1965) and Burning Ants (1967) included Jawi newspaper as one of the subjects of his paintings as indicating the time of occurance when Jawi newspapers were still produced). Other samples are as in the composition of architectural image; therefore, as calligraphy is a part of the scenery, it was then included in the painting for marginal purposes (as in sample by Zulkifli Mohd Dahalan, titled Shops (1973); by Anuar Dan, titled Shah Alam and Kapitan Keling Mosque Series (2002) and from the sample produced by Abd Shukor Yahya, titled Al-Fatihah in 2002).

Included in this categpry are Islamiccalligraphy in the form of signature, title of painting, prints on currency note and newspaper, a scribbling note in calendar and others.

E. Gestural Calligraphy/Pseudo-Calligraphy

It is a condition when no actual calligraphy is found in the work, but only the gestural strokes of brushes that nearly imitate the actual calligraphy or assumed to be. There are no meaningful words attached to this gestural or pseudo-calligraphic style of writing because none of the letters or words are legible. The samples are from the work of Syed Ahmad Jamal titles as Writing (1961); Cheong Lai Tong with Sketch (1979); and Mohamad Din Mohamad with Tenaga Khat I (1994). In the work of Syed Ahmad Jamal, the artist himself told that there are no letters nor words consists in his art work (Writing) because the main purpose of the brush strokes are as reminders of the gestural calligraphy.

\section{ACKNOWLEDGMENT}

Earnest gratitude for the galleries, institutions, museums, artists, and all person involved in providing the data and details of contemporary Malaysian calligraphic paintings, especially for National Art Gallery (now it is called National Visual Art Gallery), University of Malaya's Museum of Asian Art, UiTM Gallery, USM Gallery and Museum, Petronas Gallery, Shah Alam Gallery, Kedah Gallery, Penang Gallery, Ipoh Gallery, Terengganu Museum; Persatuan Seni Khat Kebangsaan (National Islamic Calligraphy Asociation), and all the artists and person who support this research in any way.

\section{REFERENCES}

[1] I. R. A. Faruqi, The Cultural Atlas of Islam, New York: Macmillan Publishing Company, 1986.

[2] N. M. Shabout, "Modern Arab art and the metamorphosis of the Arabic Letter," PhD Thesis, The University of Texas at Arlington, unpublished, 1999.

[3] A. Hasan, "Contemporary Islamic painting in Malaysia: 1983 to 2000," PhD Thesis, Shah Alam: UiTM, unpublished, 2010.

[4] E. Panofsky, Studies in Iconology: Humanistic Themes in the Art of the Renaissance, Oxford and New York: Harper \& Row, 1939.

[5] Al-Ghazzālī, Ma'ārij Al-Quds Fi Madārij Al-Ma'rifah al-Nafs, Cairo: Maktabah Al-Tijāriyyah al-Kubrā, n.d.

[6] N. A. Hamidon, "Islamic calligraphy in contemporary art of Malaysia," PhD Thesis, Universiti Teknologi MARA Malaysia, unpublished, 2012.

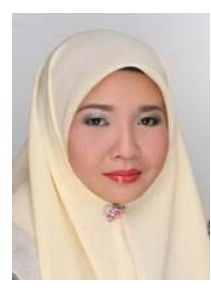

Nor Azlin Hamidon was born in Kuala Lumpur, Malaysia on September 21, 1971. She holds her first degree from the Faculty of Usuluddin, University of Malaya, Kuala Lumpur, Malaysia with first class degree in 1995. She then studied at the School of Oriental and African Studies, University of London for a year in the post graduate level: Master of History of Art and Archaeology in 1997/1998 academic session. She then proceeded to do her PhD at the Faculty of Art and 
Design, University of Mara Technology, Shah Alam, Selangor, Malaysia, completed in 2012. Her area of expertise is Islamic and Malay visual art, specializing in Islamic calligraphy.

She is, at present, a senior lecturer at the Department of Malay Arts, Academy of Malay Studies, University of Malaya, Kuala Lumpur Malaysia. In the past, she was an assistant lecturer in International Islamic University, Malaysia and afterwards becoming a Tutor in the Faculty of Usuluddin, Academy of Islamic Studies, University of Malaya. Her first book was published by Academy of Malay Studies in 2002 titled "Kesenian Melayu", written with an associated author Prof. Datin Dr. Rahmah Bujang. Numerous articles had been published. She has done many researches regarding Malay arts, done in Malaysia, Indonesia and Thailand.

Dr. Nor Azlin Hamidon was granted with the Royal Educational Award (Anugerah Pelajaran DiRaja) by the Kings Council in 1995. Her expertise in art has been recognized for being consulted as an expert for MABBIM in finalizing terms and terminologies for art, for the use in Malaysia, Brunei and Indonesia (1997). She is also a member of the IOV (International Association of Folk Art) under UNESCO and life-member of The National Association of Islamic Calligraphy in Malaysia.

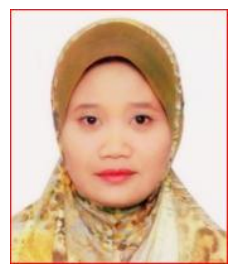

Siti Mastura Md Ishak is a lecturer in Universiti Putra Malaysia (UPM). She graduated with degree in Industrial Design at University Technology of Mara in 2001 and obtained her master in Malay art studies at the University of Malaya in 2011. Currently, she is pursuing her PhD in the University of Malaya, Kuala Lumpur, Malaysia.

She was a designer in Royal Selangor International for 8 years before working as Tutor in 2007 at UPM. She has taught Applied Design Technology, Plan and Technical Technology and Applied Design Lab in UPM. Her research interest includes Aesthetic behavioral development, product-user experience and commercial value in the cultural product design.

In 2013, Siti Mastura Md Ishak was assigned as the affiliated fellow at Goethe University, Frankfurt, Germany in Contemporary Art of Southeast Asian: Art and Design in Malaysia. She had presented articles regarding cultural design interrelationship and the Malay arts in general, within the country or abroad. 